\title{
Nieudana ucieczka przed „gębą”. Czytając Kunderę przez pryzmat Gombrowicza
}

\author{
Agnieszka Janiec-Nyitrai (Budapešt)
}

\begin{abstract}
Abstrakt
W artykule powieść Milana Kundery Życie jest gdzie indziej poddana została nowej analizie przy pomocy klasycznych już pojęć przejętych z Ferdydurke Witolda Gombrowicza - „gęba”, „pupa” i „łydka”. Poruszone zostały kwestie związane z ludzkim uzależnieniem od formy i z technikami manipulacyjnymi, nie pozwalającymi głównemu bohaterowi dojrzeć. Ważne miejsce zajmuje również stosunek Milana Kundery do twórczości Witolda Gombrowicza. Kundera przenikliwie ilustruje, iż tożsamość nie jest czymś stałym i niezmiennym. Pokazuje, jak ludzie mogą zmieniać się, często na przekór własnej woli, pod wpływem wzroku innych.
\end{abstract}

\section{Słowa kluczowe}

tożsamość; Milan Kundera; Witold Gombrowicz; komparatystyka; Życie jest gdzie indziej; Ferdydurke

\section{Abstract \\ Unsuccessful Escape from the „Mug”. Reading Kundera through Gombrowicz}

The article offers a new analysis and interpretation of the novel Life is Elsewhere by Milan Kundera using the now classic concepts from Witold Gombrowicz's Ferdydurke - „mug”, „arse” and „calf”. Issues related to human dependence on form and manipulation techniques that prevent the main protagonist from maturing are also touched upon. Finally, Milan Kundera's attitude toward the work of Witold Gombrowicz also plays an important role.

Kundera astutely illustrates that identity is not something constant and unchanging. He shows how people can change, often against of their own will and under the influence of others' eyes.

\section{Key words}

identity; Milan Kundera; Witold Gombrowicz; comparative studies; Life is elsewhere; Ferdydurke 


\section{Wstęp}

Problematyka chwiejnej, niepewnej tożsamości, tożsamości podlegającej ciągłym zmianom pod wpływem czynników zewnętrznych (tych w makro i mikro skali - od wpływów ideologii aż po wpływ innego człowieka) należy do jednych z kluczowych tematów pojawiających się w literaturach krajów Europy Środkowej. W horyzoncie badawczym krystalizuja się wtedy niezwykle ważne pytania: Jak postrzegam sam siebie, a jak widzą mnie inni? Czy podlegając nieustannym ocenom ze strony innych, zmieniam się, czy pozostaję sobą? Czy istnieje ucieczka przed tym, jak widzą mnie inni? W którym miejscu kończę się ja, a zaczyna Inny? Jakie metody stosują ludzie, by zawłaszczyć drugiego? Aż w końcu kluczowe: kim jestem naprawdę? Właśnie te pytania stanowią wyraźny punkt styczny w twórczości polskiego pisarza Witolda Gombrowicza i czeskiego prozaika Milana Kundery.

W artykule chciałaby przeanalizować powieść Życie jest gdzie indziej Milana Kundery używając pojęć, narzędzi i metod zapożyczonych od Witolda Gombrowicza. Na ślad powinowactwa obu powieści naprowadziła mnie Eva Le Grand, która w monografii poświęconej twórczości Kundery charakteryzuje powieść czeskiego pisarza jako swoistą wariację na temat debiutanckiej powieści Gombrowicza: „Tento román čtu jako poctu-variaci na Gombrowicze, na jeho sarkastickou kritiku sentimentálního lyrismu, kterou prostupuje typicky středoevropská groteska. Vzpomeňme na řáděni hloupoučkého v románu 'Ferdydurke', kde je lyrismus hlavním terčem Gombrowiczowy satiry neznalosti, mládi a jejîho modernistického imperativu." Koncentrując się na powieściach Ferdydurke (1937) i Życie jest gdzie indziej (1973) chciałaby zasygnalizować istnienie pewnych paraleli, dające się zauważyć w prozie obu pisarzy i zademonstrować, jakie nowe odczytania powieści Kundery są możliwe przy wykorzystaniu pojęć stworzonych przez Gombrowicza.

\section{Gombrowiczowskie pojęcia-klucze}

W pojęciu Gombrowicza człowiek w momencie kontaktu z innym wkłada maski, przestaje być sobą, a w skrajnych sytuacjach staje się marionetką, lustrzanym odbiciem drugiego człowieka. Ludzka egzystencja jest pełną okrucieństwa bitwą w gabinecie krzywych luster, podczas której dochodzi do wykoślawień i wypaczeń: „[...] wedtug Gombrowicza owo wspótżycie (międzyludzkie, komentarz AJN) nie jest pokojowa koegzystencja cztowieka z cztowiekiem, ale agresywna walka, ponieważ choć cztowiek odbija się w świadomości drugiego, to jego odbicie nie jest lustrzane, ale karykaturalne $i$ znieksztatcone jak w gabinecie krzywych luster. Wspótistnieć, ttumaczac na Gombrowiczowski jezyk, to być narażonym na deformacje, wypaczenie $i$ wykoślawienie, to być narażonym na przyprawienie gęby." 2 Tę egzystencjalną pułapkę Gombrowicz postanawia zbadać i uchwycić w swojej chyba najważniejszej powieści Ferdydurke, wydanej tuż przed wybuchem II wojny światowej. Na potrzeby powieści Gombrowicz

1 LE GRAND, Eva: Kundera aneb pamět touhy. Olomouc: Votobia, 1998, s. 93.

2 URBAŃSKA, Agnieszka: 'Ferdydurke', czyli studium nad Forma - o ktopotach w recepcji Gombrowiczowskiego dzieta i o recepcie na prawdziwe jego odczytanie. Postscriptum polonistyczne 14, 2014, nr 2, s. 382. 
stwarza oryginalny aparat pojęciowy, który pozwala mu zagłębiać się w skomplikowane relacje międzyludzkie. Owe pojęcia - symbole na dobre weszły do języka kultury ${ }^{3}$, co świadczy o ich uniwersalności i doskonałej przystawalności do opisywanych przez pisarza kwestii. W oryginalną symbolikę zostały wyposażone poszczególne części ciała, a dla samego pisarza, jak zauważa Jerzy Jarzębski, ciało staje się czymś w rodzaju mikrokosmosu, w którym zachodzą podobne procesy, jak w makrokosmosie. ${ }^{4}$

Gombrowiczowska "gęba” to wszystkie maski, społeczne role, które człowiek odgrywa pozostając w relacji z innymi ludźmi, to formy, do których ludzie muszą się dopasować, by istnieć w społeczeństwie. „Gęba” oznacza także schematyzm, fałszowanie rzeczywistości. To wszelka forma, którą człowiek przyjmuje w kontaktach z innymi, bądź też forma, która jest mu narzucana: „Gęba na koniec - to odpowiednik antycznej 'persony', zastygta mina - maska wttoczona na twarz każdego cztowiek $-z$ wola lub wbrew jego woli."

„Pupa” z kolei staje się u Gombrowicza symbolem zdziecinnienia, jest jedną z form „gęby”, jest gwałtem na ludzkiej naturze, na ludzkiej tożsamości. Ten, kto „upupia”, jednocześnie triumfuje, nie pozwala drugiemu na niezależność, czyni z niego wieczne dziecko, niezdolne do samodzielnego myślenia i niezależnych decyzji. „Upupienie” jest brutalną formą infantylizacji, emblematem dziecięctwa, świadomym wpędzaniem w niedojrzałość. Jak pisze Ewa Thompson, „upupić”: „[...] oznacza tyle, co przymusić kogoś do zachowania się w sposób ujawniajacy strach, brak poczucia bezpieczeństwa, sprawić, by czut się kimś nieważnym i niedojrzalym." ${ }^{\prime}$ Upupiając traktujemy kogoś z wyższością i z pobłażaniem, widzimy w nim dziecko. „Pupa” oznacza także wszystko to, co absurdalne, pozbawione logiki, jest to w pewnym sensie drwina ze świata.?

„Łydka” to trzecie z kluczowych pojęć pojawiających się w Ferdydurke. Jest to kolejna wersja "gęby", czyli zachwyt nad wszystkim, co nowe, nowoczesne, synonim burzenia starych tradycji, negacja tego, co wydaje się być przestarzałe. „Łydka” oznacza radykalne zerwanie z tradycją, pogoń za tym, co nowe, obiecujące, żywotne, nowoczesne. „Łydka” ma również wyraźny podtekst seksualny.

\section{Gombrowicz według Kundery}

Kundera w swoich eseistycznych uwagach reflektujących twórczość własną i innych autorów często uwzględnia intelektualne dziedzictwo Witolda Gombrowicza oraz jego wkład w rozwój środkowoeuropejskiej i w ogóle światowej powieści. Nazwisko polskiego pisarza pojawia się w towarzystwie najwybitniejszych postaci europejskiego życia kulturalnego XX wieku, należy do panteonu reprezentowanego przez Hermanna Brocha, Franza

3 GARBAL, Łukasz: Ferdydurke. Biografia powieści. Kraków: Universitas, 2010, s. 149-166.

4 JASTRZĘBSKI, Jerzy: Anatomia Gombrowicza. Teksty: teoria literatury, krytyka, interpretacja, 1972, nr 1, s. 115 .

5 Tamże, s. 116.

6 THOMPSON, Ewa: Witold Gombrowicz. Katowice: Wydawnictwo Uniwersytetu Śląskiego, 2002 , s. 84.

7 BŁOŃSKI, Jan: Między buntem a ucieczka. 'Ferdydurke’ Witolda Gombrowicza. Teksty Drugie, 2009, nr 3, s. 246-247. 
Kafkę czy Roberta Musila. Najobszerniej Kundera pisze o twórczości Witolda Gombrowicza w eseju Nechovejte se tu jako doma, př́teli. Gombrowicz w ujęciu Kundery staje się wiecznym kontestatorem, człowiekiem, który całym swoim życiem i całą swoją twórczością protestował przeciw zaszufladkowaniu, bronił swojej wolności twórczej i osobistej. Powieść Ferdydurke nazywa Kundera genialną, podkreśla jej nowatorskość, radykalizm, jednocześnie żałując, że została odkryta tak późno. ${ }^{8}$

Ciasne ramy literatur narodowych ograniczają interpretacje powieści takich autorów jak Gombrowicz, co jednak może budzić pewne kontrowersje - twórczości środkowoeuropejskich pisarzy nie da się bowiem oddzielić od ich naturalnych narodowych kontekstów, jak podkreśla Světlana Šerlaimová pisząc o Kunderze i Gombrowiczu. ${ }^{9}$ Według Kundery polski pisarz, przebywający od roku 1939 na emigracji, określił sam siebie jako twórce poprzez trzykrotną negację - zanegowanie politycznego zaangażowania polskiej emigracji, odrzucenie polskiej tradycji, a także odejście od tego, co proponowali zachodnioeuropejscy twórcy moderny lat $60 .{ }^{10}$ Kundera podkreśla również, iż powieści Gombrowicza można uznać za bunt przeciwko kanonowi powieściowemu XIX wieku, jednak według czeskiego pisarza autorowi Ferdydurke nie przyświeca chęć pogoni za nowatorstwem, przeciwnie, obnaża on pustkę powierzchownego buntu przeciwko wszystkiemu, co stare, przebrzmiałe. ${ }^{11}$ Gombrowicz staje się dla Kundery synonimem niezależnego twórcy, a w jego twórczości fascynuje go właśnie motyw wyjścia z szeregu, próba pozostania sobą bez względu na okoliczności. Czeski pisarz został nawet uznany za głównego propagatora dzieła Witolda Gombrowicza w Czechach, choć Kundera koncentruje się w swoich uwagach głównie na wkładzie Gombrowicza w rozwój powieści, pomijając niejako jego twórczość dramaturgiczną, choć, jak się wydaje, Czesi na przełomie lat 60. i 70. zetknęli się najpierw z dramaturgiczną twórczością Gombrowicza. ${ }^{12}$ Kundera nawiązuje do twórczości Gombrowicza również w swojej beletrystyce. Jak zauważa Roman Kanda, pisarz w powieści Nieśmiertelność eksponuje pojęcie gestu w podobnym kontekście jak Gombrowicz - jako czegoś bardziej indywidualnego niż człowiek jako indywiduum. ${ }^{13}$

Kundera, podobnie jak autor Ferdydurke, podsuwa czytelnikom i krytykom interpretacje swoich utworów. To również łączy obu pisarzy - poczucie, iż tekst, który wyszedł spod ich pióra, należy do nich, jest ich własnością. Kundera potwierdza to szczególnie we wspomnianym już eseju Nechovejte se tu jako doma, přiteli, a Gombrowicz wykłada swoje dzieła np. w licznych fragmentach Dzienników, które o wiele bardziej niż zapisem życia codziennego stają się zapisem zmagań twórcy z własnym dziełem.

8 KUNDERA, Milan: Nechovejte se tu jako doma, př́teli. Brno: Atlantis, 2006, s. 40-42.

9 ŠERLAIMOVA, Světlana: Český román a evropský kanon. In: Otázky českého kanonu. Praha: Ústav pro českou literaturu, 2006, s. 62.

10 KUNDERA, Milan: Nechovejte se tu jako doma, př́teli. Op. cit., s. 40.

11 SOLIŃSKI, Wojciech: Gombrowicz w Czechach? In: CUDAK R. (eds.): Literatura polska w świecie. T. 3, Obecności, Katowice: Wydawnictwo Uniwersytetu Śląskiego, 2010, s. 212.

12 Op. cit., s. 205-206.

13 KANDA, Roman: Gesto - detail - forma. K některým aspektům tvorby Witolda Gombrowicze. Aluze, 2011, č. 2, s. 56. 
Kundera sam uznaje Gombrowicza za jednego z najważniejszych pisarzy XX wieku ${ }^{14}$ i nie ulega wątpliwości, że pisarstwo Gombrowicza - radykalne, głęboko filozoficzne, semantycznie niezwykle bogate i inspirujące, ale jednocześnie nieoderwane od życia mogło być inspiracją nie tylko refleksji dotyczących sensu powieści w XX wieku, ale także dla samej twórczości powieściopisarskiej Kundery.

\section{Kundera według Gombrowicza}

\subsection{W sidłach „gęby”}

Drugą powieść Milana Kundery Życie jest gdzie indziej można uznać za swoiste studium skomplikowanych relacji międzyludzkich polegające na nieustannym przyprawianiu „gęby" drugiemu człowiekowi, wpychaniu go w rolę, która jest dla niego niewygodna i uciekaniu w "gębę" przed skomplikowanym światem. Niemal każdy każdemu wciska na twarz maskę, gombrowiczowska „gębę", co więcej sami bohaterowie wpadają z jednej formy w drugą, skrywają się za "gębami”. Konsekwencje owej „gry masek” mają dalekosiężne skutki. Matka głównego bohatera przypłaca swoją relację z kochankiem artystą malarzem silnym załamaniem nerwowym, ponieważ maska wyzwolonej kochanki i dziwne eksperymenty seksualno-artystyczne pozostają w niezgodzie z jej naturą. „Gęba”, do której noszenia zmusza ją malarz, uwiera ją, dusi, niszczy. W końcu sama z ulgą skrywa się za kolejną rolą społeczną - maską, „przyprawiając sobie gębę” matki, która rezygnuje ze związku z malarzem ze względu na dobro swego syna. Bohaterka pisze list do malarza, w którym usprawiedliwia swoją decyzję o rozstaniu: „Na konci psani už sama věrila, že to nebylo jeji břicho ani namáhavý běh za malírovými nápady, co zpiosobilo jeji nervovou krizi, nýbrž jen jeji velké mateřské city, které se vzbouřily proti velké, ale hřišné lásce. " ${ }^{15}$

„Gębę" przyprawia bezimiennej bohaterce także jej własny syn, a ona podlega jego wpływowi, choć jasne jest, że znów chodzi o coś obcego, niezgodnego z jej przekonaniami: „Jak jsou si oba podobni, matka i syn! Oba jsou stejně uhranuti nostalgii po monistickém ráji jednoty a harmonie [...] Jak syn dospíval, snažila se, aby byla kolem něho $i$ nadále obestřena jak vzdušná náruč, přijala všechny jeho názory, vyznává moderni uměni, hlási se ke komunismu, věrí v synovu slávu, rozhořčuje se nad obojetnictvím profesorů, kteř́ včera mluvili něco jiného než dnes, chce být kolem něho jako obloha, chce být stále ze stejné hmoty jako on. "16 Matka nie może zaakceptować, iż jej syn jest odrębnym bytem, kimś innym, zaczyna żyć jego życiem.

Jednocześnie jednak sama matka głównego bohatera - młodego poety Jaromila - jest mistrzynią w przyprawianiu „gęby”. Wynikiem jej eksperymentów jest właśnie syn - wypadkowa jej marzeń, snów i wyobrażeń. Całe życie młodego poety jest ucieczką przed "gębą” „zgotowaną" mu przez matkę. Jaromil na próżno stara się strząsnąć ciężar, ów wątpliwy dar "gęby”, ale wciąż widzi w sobie podobieństwo do matki: „Jaké to bylo břemeno,

14 ČEŠKA, Jakub: Barthes, Kundera, Gombrowicz. World Literature Studies 2 (19), 2010, č. 3, s. 63.

15 KUNDERA, Milan: Život je jinde. Toronto: Sixty Eight Publishers, 1979, s. 66.

16 Tamże, s. 259. 
nést tuto tváṛ̆! Jak těžká byla ta lehoučká kresba rysů."17 Matka i jej zwodniczy cień są obecne zawsze i wszędzie: „A protože věděl, že se na něho ostatni zase divají, začal si na sobě palčivě uvědomovat svou tvár̆ a skoro s úděsem cítil, že to, co má ve tvárí, je maminčin úsměv! [...] Cítil, že má na obličeji vsazenou maminku, že ho maminka oblepila jako kukla oblepuje larvu, které nechce dopřát právo na vlastni podobu. A tak tu seděl mezi dospělými lidmi zakuklen do maminky, která ho objímala a táhla zpátky z toho světa, do kterého chtěl náležet, a který se $k$ němu choval vlidnè, ale přece jen jako $k$ někomu, kdo do něj ještě nepatř́. Bylo to tak nesnesitelné, že Jaromil sebral všechny své síly, aby se sebe matčinu tvár̆ setřásl, aby z ni vykročil [...]“.. Jaromil nigdy nie może być sobą, ponieważ matka nie dała mu szansy stać się sobą. Ustawicznie „upupiany” i z przyklejoną „gębą” jest tak naprawdę tylko pustym naczyniem, w które ktoś wlewa treść.

Nieco inaczej gombrowiczowska „gęba” manifestuje się w przypadku Rudej - kochanki Jaromila. Ruda jest wtłoczona w schemat, zaszufladkowana przez Jaromila i jego matkę jako człowiek z ludu. Nie widzą w niej człowieka, ale jedynie jego pochodzenie społeczne, figuruje w ich wyobrażeniach jako nieco nieokrzesana, niewychowana kasjerka ze sklepu, pozbawiona wyższych uczuć, i, w przypadku Jaromila, obiekt seksualnych pragnień.

Wizja, którą proponuje Kundera, jest jednak inna niż u Gombrowicza - tam główny bohater staje się niejako reżyserem owej „gry gąb”, potrafi zdystansować się od okoliczności, zdarzeń i sytuacji: „Bohater Ferdydurke Gombrowicza jest wręcz biologicznie predestynowany do tego, aby - zamiast, jak inni, podporzadkowywać sie różnym, gębom i wrastać w nie bez reszty niczym paznokieć w palec - dystansować się wobec nich i grać nimi, demaskować je i przedrzeźniać. Dlatego zamiast pozwolić im rzadzić soba, sam staje sie podmiotem i reżyserem otaczajacej go gry gab; napuszcza je na siebie, konfrontuje ze soba, ośmiesza." 19 Kundera proponuje mroczniejszą wersję - w powieści Życie jest gdzie indziej bohaterowie nie sa świadomi własnego odczłowieczenia, nieautentyczności, jedynie Jaromil w rzadkich przebłyskach świadomości zdaje sobie sprawę, iż jest sterowany przez matkę, iż sam przybiera pozy jak malarz, że „kradnie” inne tożsamości z braku własnej.

\subsection{Uciekając przed „pupą”}

Jaromil jest również ofiarą nieustannego „upupiania”. Matka wciąż „upupia” go, a owo „upupianie” przyjmuje jak najbardziej konkretne formy. Poprawianie Jarmilowi przy gościach pracowicie wystylizowanej przez niego fryzury: „Můj Bože, jak ty vypadáš, zděsila se nahlas, když spatřila synưv pečlivě rozcuchaný účes. Donesla hřeben a neustávajíc v konverzaci s návštěvou, vzala mu hlavu do rukou a česala ho. A veliký básnik, nadaný d’ábelskou fantazií a podobný Rilkemu seděl, rudý a vzteklý, a nechal se česat, jediné, na co se zmohl, byl surový úsměšek (ten dlouhá léta cvičený), který so nechal ztuhnout na tváři. “20, zmuszanie go do prze-

17 Tamże, s. 113.

18 Tamże, s. 173.

19 DYBEL, Paweł: Gombrowicza gra w gęby albo gra gab. Przestrzenie Teorii, 2012, nr 20, s. 32-33.

20 KUNDERA, Milan: Život je jinde. Toronto: Sixty Eight Publishers,1979, s. 135. 
bierania się przy matczynych koleżankach ${ }^{21}$, ustawiczne śledzenie, strofowanie, kontrola... Matka nie chce, żeby syn dorósł, ma być zawsze jej kochanym małym, utalentowanym i wrażliwym synkiem. Ubiera go, przygotowuje co rano ubrania, bieliznę, kontroluje go wciąż, nie daje mu dojrzeć. Jaromil nie może wyrwać się z opresji, z nieustannego nękania psychicznego.

Kluczowym momentem jest scena, kiedy podczas kręcenia filmu, w którym Jaromil jest głównym bohaterem, bohater czyta swoje wiersze na filmie poruszając niemo ustami jak ryba: „' Proboha', volala na něho filmařka už netrpèlivě, , musíte je otevírat přesně na slova své básnĕ, ne jen tak, jak se vám zachce. Ten herec to přece musi namluvit na pohyby vašich úst!‘ A tak stál Jaromil před balvanem, otevíral ústa (poslušně a přesně) a kamera se konečně rozzvučela."22 Jaromil pozostaje wciąż w lacanowskim „stadium lustra”. Jak pisze Agnieszka Doda-Wyszyńska: „Stadium lustra to częściowo nieudane wejście w porzadek symboliczny. Jakaś część rzeczywistości musi pozostać nieusymbolizowana. Wedtug J. Lacana, czas stadium lustra pokrywa sie z czasem 'tranzytywizmu dzieciecego', schwytania przez obraz innego. Na przyktad dziecko, bijac innego, mówi, że on je zbit." Jest to pewne zaburzenie, niewyksztatcenie, niedorozwój odpowiedzialności za wtasne czyny." ${ }^{33}$ Bohater jest często pokazany, kiedy przegląda się w lustrze, jakby wciąż chciał potwierdzić, sprawdzić, kim jest naprawdę, świadczy to o jego niedojrzałości i charakterystycznej dla dzieci fascynacji własnym odbiciem. Jaromil nie jest ,jednolity”, nie jest gotowy, wciąż znajduje się w stadium dojrzewania, składa się z wielu nieprzystających do siebie kawałków, co jest wynikiem ciagłego i natarczywego „upupiania” przez matkę. Spędza czas przed lustrem ćwicząc grymasy, gesty, uśmiechy pełne wyższości, aby wyglądać na dorosłego, po męsku. ${ }^{24}$

Według Lacana cały czas stoimy przed lustrem, tożsamość więc jest czymś niegotowym, wciąż mającym swoje tajemnice. Według Lacanowskiej psychoanalizy dziecko stając naprzeciw lustra konfrontuje się z samym sobą, który jest jednocześnie Innym, kimś drugim. Chodzi o swego rodzaju pierwotną identyfikację dziecka, oczywiście „stadium lustra" rozumiane być może w sposób symboliczny. Lustrem, w którym przegląda się człowiek, w naszym przypadku Jaromil, są inni ludzie, a w szczególności matka. „Matka jest przecież, w perspektywie genetycznej, pierwszym innym, jaki zjawia sie dziecku w lustrze swiata. Samo dziecko jako podmiot doświadczajacy pokawatkowania wtasnego ciata [...] jest na razie czymś w rodzaju pustej tablicy, na której, aby mogto wyjawić się dla siebie jako wtasne 'ja', inny musi najpierw odcisnać swój ślad. Dlatego, zanim podmiot wykształci swój lustrzany obraz (imago) jako ' ja', zrazu utożsamia (mylnie) siebie z ujrzanym pierwotnie w lustrze obrazem innego - matki." ${ }^{\prime 5}$ Jaromilowi do końca nie udaje się uwolnić od owego niszczycielskiego utożsamiania się z matką, umiera w jej ramionach nie odnalazłszy nigdy sam siebie.

21 Tamże, s. 184-185.

22 Tamże, s. 287.

23 DODA-WYSZYŃSKA, Agnieszka: Dziecko przed lustrem, czyli w poszukiwaniu swojego miejsca. Studia Kulturoznawcze 1, 2011, nr 1, s. 103.

24 KUNDERA, Milan: Život je jinde. Op. cit., s. 147.

25 DYBEŁ, Paweł: Lacan i Leśmian: dwa zwierciadta. Teksty Drugie: teoria literatury, krytyka, interpretacja, 1998, nr 1/2 (49/50), s. 28. 
„Upupianie” rozumiane w szerszy sposób staje się udziałem całego czechosłowackiego społeczeństwa, wystawionego na szykany po roku 1948. Ludzie są traktowani jak dzieci, wiersze przeznaczone dla „komunistycznego człowieka” przyszłości muszą być chwytliwe, jasne, latwe w odbiorze, jednoznaczne, poezja ma nie pozostawiać żadnej przestrzeni interpretacyjnej. Ludzie mają pozostawiać w stanie permanentnej niedojrzałości, łatwiej nimi wtedy manipulować, są ubezwłasnowolnieni. Ten, kto jest niedojrzały, jest łatwiejszy do sterowania. Ludzie, podobnie jak u Gombrowicza, ${ }^{26}$ stają się zakładnikami gier, stają się aktorami wyreżyserowanych rytuałów, których nie rozumieją. Wiedzą, że nad nimi rozciaga się jakiś autorytet, ktoś, kto wie lepiej, ktoś, kto czuwa, sprawdza, upomina, ktoś, kto ma zawsze rację. System komunistycznej kontroli jest tak zbudowany, aby te osobniki, które odważą się myśleć niezależnie, były eliminowane ze społeczeństwa, jak bohater debiutu powieściowego Kundery Żart Ludvík Jahn.

\subsection{Zafascynowani „tydką"}

Niedojrzałość głównego bohatera powieści Życie jest gdzie indziej ma także swoje inne konsekwencje. Jaromil jest zafascynowany tym, co nowe, tym, co przynosi z sobą komunistyczna rewolucja w 1948 roku. Wierzy w nowy, lepszy świat, podlega złudnej wierze, że świat można zrewolucjonizować, cechuje go wiara w przemianę świata, naiwna wiara w komunizm i w moc poezji. Bunt Jaromila jest oczywiście naiwny, bohater stara się przeciwstawić tradycji, uosabianej w pewien sposób przez matkę, ale także przez stryja.

Ważną rolę w kontekście gombrowiczowskiej „łydki” pełni także seksualność - jest to droga, którą Jaromil podąża pragnąc uciec od matki i przed matką, w konsekwencji tego ucieka jednak tylko z jednego łona w drugie, wpada w kolejną pułapkę ubezwłasnowolnienia. Tak bardzo chce dorosnąć, że nie widzi, iż ucieka z jednej niewoli w drugą.

Gombrowiczowska „łydka” - udawana spontaniczność, energiczność, zdecydowanie należały do ważnych elementów wychowania komunistycznej młodzieży na wartościowe nowe pokolenie, wolne od zabobonów przeszłości. Jaromil chce być właśnie taki - postępowy, nowoczesny, męski, zdecydowany, ale wszystkie jego starania sprowadzają się do nakładania kolejnych masek, kolejnych nieudanych prób znalezienia własnej tożsamości w szybko zmieniających się czasach. „Revoluce stejně jako lyrika nesnáši kritickou distanci, vyžaduje bezpodmínečnou viru, euforii, naďseni, splynuti s jejimi cilil." ${ }^{27}$ Właśnie taki, zaślepiony wizją przyszłości, niekrytyczny, ogłupiony narkotykiem rewolucji jest Jaromil.

Tragicznym symbolem „lydki” staje się również Ruda - przedstawicielka pracującego proletariatu, nadzieja komunistycznego społeczeństwa, która, podobnie jak gombrowiczowska Ziuta, bohaterka „Ferdydurke”, jest jednocześnie bardzo aktywna seksualnie. W powieści Kundery jednak właśnie ta postać, emblematyczny bohater swoich czasów, pierwowzór „nowego człowieka”, zostaje brutalnie potraktowana - na podstawie donosu Jaromila jest zaaresztowana i „złamana” w więzieniu. Kundera pokazuje, jak rewolucja pożera własne dzieci, niszczy własne tkanki, jak jest ślepa i pozbawiona logiki.

26 KANDA, Roman: Gesto - detail - forma. K některým aspektiom tvorby Witolda Gombrowicza. Op. cit., s. 56. 


\section{Wnioski końcowe}

Gombrowicz w powieści Ferdydurke protestował przed deformacją ludzkiej tożsamości, przed zniekształcaniem, wykoślawianiem tego, co jest w człowieku autentyczne. Dramat „upupienia”, zaklęcia w formę, staje się także udziałem bohaterów powieści Życie jest gdzie indziej, która staje się niejako traktatem o zakleszczaniu w formę, tragicznie groteskową przypowieścią o niszczeniu człowieka przez człowieka, o trudnym i wyczerpującym poszukiwaniu własnego ja: „Hlavni činnosti Jaromila je jeho neustále a úpěnlivě obnovovaný pokus definovat sama sebe. Totéž plati i o jeho matce a o všech ostatnich postavách románu v té míre, ve které jsou rozvinuty. Bez oddechu putuji z jedné role do druhé, hraji či předstíraji, vymýšleji si své úlohy nebo je prijimaji od druhých." ${ }^{28}$ Człowiek nie może istnieć w społeczeństwie bez atrybutów nadanych mu przez ludzi, wśród których żyje, ale jednocześnie owo „upupianie”, wtłaczanie w formę niesie za sobą poważne konsekwencje - może oznaczać rozchwiania ludzkiej tożsamości, frustrację, niekończące się pytania - kim właściwie jestem? „Gęba”, „pupa” i „łydka” nie są niegroźnymi etykietkami, nie chodzi tylko o zaszufladkowanie, o grę masek społecznych. Na oczach czytelników powieści Kundery rozgrywają się prawdziwe egzystencjalne tragedie pokazujące walkę o własną tożsamość.

Kundera niezwykle przenikliwie ilustruje, iż tożsamość nie jest czymś stałym i niezmiennym. Pokazuje, jak ludzie moga zmieniać się, przepoczwarzać, często na przekór własnej woli, pod wpływem wzroku innych. „Nasadzając gębę” sobie i innym człowiek sprzeniewierza się autentyczności, prawdzie, ale jednocześnie dzięki temu może współistnieć w świecie z drugim człowiekiem.

Postacie Kundery wpadają w tę samą pułapkę, co postacie Gombrowicza - walcząc o swoją suwerenność, uciekając przed „gębą” wpadają w pułapki kolejnej „gęby”. Każdy z bohaterów powieści Kundery jest na swój sposób zniewolony, podlega automatyzmowi, jest jak zdalnie sterowana zabawka pozbawiona własnej woli. Jaromil, wprawiony w ruch władczą ręką swej matki, bezwiednie zmierza ku tragicznemu końcowi, ku śmierci, nic nie zrozumiawszy, nic nie odkrywszy, niedojrzały, niepewny, „upupiony” i wyposażony w ciążąca mu „gębę”, która go ciągnie na dno. Wydźwięk powieści jest Kundery podobny jako dzieł Gombrowicza: „Gombrowiczova dila 'ze smetiště chtěji odhalit divadlo světa tím, že osvětluji plochost kulis, hranost gest a umělost formy, že - chceme-li pokračovat v tomto přměru - nezaměňuji tvár̆ člověka s maskou nebo hereckým líčidlem. Gombrowiczova díla ukazuji, že tím hlavnim jevištěm je 'smetiště', vše odložené, co může prozradit iluzivnost hereckého výstupu, který je nepřípadně prezentován jako fragment skutečnosti samé." ${ }^{29} \mathrm{I}$ u Kundery i u Gombrowicza człowiek jest niewolnikiem poglądów innych ludzi, schwytany jest w formę, jego tożsamość, o ile zdoła się w ogóle wykształcić, podlega ciągłym deformującym ją eksperymentom.

Twórczość obu autorów ma demistyfikacyjny charakter. Obaj powieściopisarze odsłaniają bezlitośnie mechanizmy, którymi rządzi się świat, czynią to z chirurgiczną precyzją, stając się jednocześnie ważnym głosem dla swojego pokolenia. W wyrafinowany artystycznie

28 RICHTEROVÁ, Sylvie: Eseje o české literatuře. Brno: Pulchra, 2015, s. 428-429.

29 KANDA, Roman: „Gesto - detail - forma. K některým aspektům tvorby Witolda Gombrowicze. Op. cit., s. 56. 
sposób badają i oświetlają, używając metafory Milana Kundery, pułapkę, którą stał się świat. Pułapka ta często przybiera bowiem formę kontaktów międzyludzkich, które zmieniają się w pole walki między dominującym a zdominowanym, między tym, kto chce uciec od „gęby”, a tym, kto ową „gębę” pragnie drugiemu nałożyć.

PhDr. Agnieszka Janiec-Nyitrai, Ph.D.

Ústav slovanské a baltské filologie, FF ELTE Múzeum krt. 4 D, 1088 Budapešt', Mad’arsko janiec.nyitrai@gmail.com 